\title{
Wife's Support, Access to Health Services, Availability of Competent Health Personnel and Infrastructure and Intention to Have a Vasectomy for Married Men
}

\author{
Tjahja Bintoro' ${ }^{1}$, Bhisma Murti², Endang Sutisna ${ }^{2}$, Suwarto $^{3}$ \\ ${ }^{1}$ Doctoral student, Universitas SebelasMaret, Solo, Indonesia, ${ }^{2}$ Professor Public health department, Universitas \\ SebelasMaret, Solo, Indonesia, ${ }^{3}$ Professor Agriculture department, Universitas SebelasMaret, Solo, Indonesia
}

\begin{abstract}
Family planning (FP) including vasectomy has positive effects in terms of viable socio-economic development and in reducing maternal deaths. The percentage of married men who use condoms (3\%) is higher than the percentage who choose vasectomy (less than 1\%). The study was conducted in the Madiun town administration using a community-based cross-sectional study design. The town is found in East Java Province, Indonesia. The total sample of this study is 323 married man with fixed disease sampling. Age of wife, wife's support for vasectomy family planning, access to vasectomy family planning health services and availability of health resources and health infrastructure for vasectomy family planning relates to the selection of men to use vasectomy. In general, vasectomy is seen as one of the least preferred method of family planning and is associated with fear and weakness.
\end{abstract}

Keywords: Family planning, structural equation model, theory planned behavior, vasectomy.

\section{Introduction}

The impact of the demographic bonus on economic growth and development has resulted in an increase in public saving and national saving, which leads to a better level of social welfare. Judging from the current demographic structure of Indonesia, in 20202030 Indonesia has the opportunity to experience a demographic bonus. The country of Indonesia will have around 180 million people of productive age, while those who are not productive will reduce to 60 million people. This means that 10 people of productive age will bear 3-4 people of non-productive age ${ }^{(1)}$. This high number of people might result in a decrease in Growth Domestic Product (GDP) and increased pressure on resource

\section{Corresponding Address:}

\section{Tjahja Bintoro}

P.O. Box: 57126. Doctoral student, Universitas Sebelas Maret, Ir. Sutami Street No. 36, Solo, Central Java, Indonesia

e-mail: btjahja34@student.uns.ac.id

Phone Number: +6281239870268 distribution $^{(2)}$. It is also affected by high maternal morbidity and mortality related to unintended and unwanted pregnancies. The goal of family planningall over the world has attracted attention due to its importance in decision making about population growth and development issues ${ }^{(3)}$. Worldwide, using contraceptives potentially reduced maternal mortality by $44 \%{ }^{(4)}$. Family planning (FP) including vasectomy has positive effects in terms of viable socio-economic development and in reducing maternal deaths ${ }^{(5)}$. Contraception has clear health benefits since the prevention of unintended pregnancies results in a subsequent decrease in maternal morbidity and mortality ${ }^{(6)}$.

Regrettably, most family planning programs in Indonesia have mostly targeted women, and men often do not take part in reproductive health matters. The male participation rate in using contraceptives in Indonesia is still very low, namely only $2.1 \%$ of male family planning participants and they generally use condoms. This percentage is lower when compared to other countries, such as Iran (12\%), Tunisia (16\%), Malaysia (9-11\%), even in the United States it reaches $32 \%$. Very few men want to use contraceptives, either condoms or vasectomy. Of the total number of family planning 
acceptors in Indonesia, around $97 \%$ are women. Therefore, the socialization of family planning programs among men must be increased ${ }^{(7)}$. The target of male family planning acceptors is $4.3 \%$ based on the strategic plan of the National Population and Family Planning Agency of Indonesia 2015-2019. The participation of men in East Java as family planning acceptors is only $1.66 \%$ (Puspita, 2019). Based on data from the health profile of the city of Madiun, the coverage of active family planning participants in 2018 was $67.7 \%$, which is 20,335 participants from a total of 30,038 PUS (BPS estimation projections). When compared with the real fertile age couples, which was 26,241 couples of reproductive age, the coverage of active family planning participants was $77.19 \%$. When compared with the achievements in 2017, active family planning participants were $77.2 \%$, experiencing a decrease. Based on data on contraceptive use in active family planning participants in Madiun City in 2018, it was found that only $0.9 \%$ used the male surgery method ${ }^{(8)}$.

One way to foster male involvement in family planning is to provide couples more contraceptive choices through the promotion of male-oriented method including vasectomy. Vasectomy is a safe, simple, and effective method that is comparatively under used throughout the world. Although sterilization is the most widely used contraceptive method worldwide, tubal ligation accounts for more than five times as many procedures as vasectomy ${ }^{(9-12)}$. Vasectomy is a surgical method used in men to cut ortie the vas deferens. The vas is a tube that delivers sperm from the testicles. The purpose of vasectomy is to provide permanent birth control for men who do not want more children ${ }^{(13)}$. It is a permanent method of family planning, which is quite acceptable in many developed countries of the world ${ }^{(13,14)}$. However in Indonesia, there are still prevailing barriers to its acceptance by married men ${ }^{(7)}$. Worldwide $19 \%$ of women in combination are sterilized (through tubal ligation) versus $2.4 \%$ men by vasectomy ${ }^{(9)}$.

Different reviewed literature reports showed that the intention to use vasectomy was associated with different variables $^{(15-18)}$. Age, educational status, occupation, religion, Cultural beliefs, societal norms, lack of knowledge about the procedure for a vasectomy, and misconceptions were found to be predictors of intention to use vasectomy. In addition, the duration of married time, number of living children, complete family size, the future desire of more children, accessibility of service, level of knowledge, and attitude of men towards vasectomy have an influence on intention to use vasectomy ${ }^{(18-21)}$. Based on the previous studies conducted on acceptance of vasectomy, this study is aimed at describing the factors affecting the intention to accept vasectomy among married men in East Java, Indonesia.

\section{Method}

The study was conducted in the Madiun town administration using a community-based cross-sectional study design. The town is found in East Java Province, Indonesia. The sampling method used for the case group and the control group is fixed disease sampling, which is a sampling scheme based on the disease status of the subject, which is diseased or has no disease studied, while the subject's exposure status varies according to the subject's disease status ${ }^{(22)}$. The estimated number of cases and control groups uses a ratio of 1: 3 in each case. The case group in this study was the husband who was willing to be a vasectomy acceptor with a total of 85 married men while the control group was taken from a husband who did not use a vasectomy with a total of 248 married men. The total sample of this study was 323 married men. All of the questionnaires were prepared in Indonesian. The variables used in this study were wife's support for vasectomy family planning, access to vasectomy family planning health services and availability of health resources and health infrastructure for vasectomy family planning. All questionnaires used in this study were valid for use ${ }^{(23)}$. Data were collected from January to February 2020. Tables, frequencies, and proportions are used to present the data. The association between dependent and independent variables was determined using the structural equation model. Logistic regression analysis was performed to analysis data.

\section{Results}

Characteristics of married men following the study are addressed in Table 1. Overall 323 married men were 45.5 years of age, where the average age of marriage was 26.5 years. The average age of a married man's wife is 40.5 years. $65.63 \%$ of married men have a high school education level and $0.62 \%$ are out of school. $33.44 \%$ of married men's jobs are entrepreneurs and $2.48 \%$ are farmers. $79 \%$ of respondents had positive wife support. $69 \%$ of respondents have good access to vasectomy family planning health services. $79 \%$ of respondents have a positive availability of health resources and health infrastructure for vasectomy family planning. 
Table 1 Sample and variable characteristics for this study

\begin{tabular}{|l|c|}
\hline Characteristics of Respondents (n=323) & Frequency (\%) \\
\hline Age (mean) & 45.5 year \\
\hline Wife's age (mean) & 40.5 year \\
\hline Education level & $2(0.62 \%)$ \\
\hline No school & $19(5.88 \%)$ \\
\hline Elementary school & $57(17.65 \%)$ \\
\hline Middle School & $212(65.63 \%)$ \\
\hline High school & $33(10.22 \%)$ \\
\hline Higher education & $21(6.50 \%)$ \\
\hline Employment & $96(29.72 \%)$ \\
\hline Government employees & $77(23.84 \%)$ \\
\hline Private employees & $8(2.48 \%)$ \\
\hline Labor & $13(4.02 \%)$ \\
\hline Farmers & $108(33.44 \%)$ \\
\hline Driver & $18(21 \%)$ \\
\hline Enterpreneur & $67(79 \%)$ \\
\hline Wife's support for vasectomy family planning \\
\hline Positive & $78.32 \%)$ \\
\hline Negative & $59(69 \%)$ \\
\hline Access to vasectomy family planning health services \\
\hline Less & $19 \%)$ \\
\hline Enough & \multicolumn{2}{|l}{} \\
\hline Good & $18 \%)$ \\
\hline Availability of health resources and health infrastructure \\
for vasectomy family planning
\end{tabular}

Table 2 Correlation between variable

\begin{tabular}{|l|c|}
\hline Characteristics of Respondents $(\mathbf{n}=\mathbf{3 2 3})$ & $\mathbf{p}$ value \\
\hline Age (mean) & 0.09 \\
\hline Wife's age (mean) & 0.03 \\
\hline Education level & 0.02 \\
\hline Employment & 0.67 \\
\hline Wife's support for vasectomy family planning & 0.01 \\
\hline $\begin{array}{l}\text { Access to vasectomy family planning health } \\
\text { services }\end{array}$ & 0.00 \\
\hline $\begin{array}{l}\text { Availability of health resources and health } \\
\text { infrastructure for vasectomy family planning }\end{array}$ & 0.02 \\
\hline
\end{tabular}

Correlation between variables are addressed in Table 2. Wife's age and occupation have nothing to do with the choice of vasectomy contraception. Age of wife, wife's support for vasectomy family planning, access to vasectomy family planning health services and availability of health resources and health infrastructure for vasectomy family planning relates to the selection of men to use vasectomy.

\section{Discussion}

Family support is a form of interpersonal relationship that includes attitudes, actions and acceptance of family members, so that family members feel someone is paying attention $^{(24)}$. The results of this study are supported by the results of previous studies where there is a significant relationship between family support (wife) on the choice of vasectomy family planning ${ }^{(25)}$. The wife's support is very influential on the husband as an acceptor of family planning, namely the wife's support in the form of communication between husband and wife in the choice of family planning method, namely counseling to increase men's knowledge about family planning, it is also necessary to provide counseling to the wife so that the delivery of information about male FP is more easily accepted by men because it is given by his wife. The wife's response to the vasectomy that the husband will do is support the husband. The wife's response can be positive or negative depending on her knowledge, attitudes, beliefs and actions ${ }^{(26)}$.

The simple logistic regression test results prove that access to vasectomy services is one of the variables that has an influence on the behavior of men doing vasectomy. The reality that occurs in the field is that access to health services for respondents is quite affordable. Most of the respondents went to health care facilities on foot and using private vehicles. The effect on access to affordable health services has not become a stimulation in Madiun City to increase the number of vasectomy acceptors due to other factors such as lack of support and access to information about vasectomy.

The availability of health resources and health infrastructure makes the tendency to participate in vasectomy family planning, on the other hand, the absence of health resources and health infrastructure becomes an obstacle for respondents to actively participate in vasectomy KB. This becomes natural if the respondent does not participate in the vasectomy family planning, because the availability of medical resources 
and infrastructure is quite negative by the respondents. Health service is one of the parameters to determine the health status of the community ${ }^{(27)}$, besides that Ariyanti, Dasuki and Wilopo (2017) ${ }^{(28)}$ In his research, he said that the availability (quantity and distribution) of health resources based on area played a role in achieving family planning programs, especially family planning needs were not met. One of the factors that influence health behavior is the availability of health resources and health infrastructure. Access to quality family planning (KB) services is an important element in the effort to achieve reproductive health services ${ }^{(29)}$.

\section{Conclusion}

The choice of vasectomy contraception in men is influenced by several factors, namely the age of the wife, wife's support for vasectomy family planning, access to vasectomy family planning health services and availability of health resources and health infrastructure for vasectomy family planning. Positive wife support, good access to vasectomy family planning health services and availability of good health resources and health infrastructure for vasectomy family planning will increase men's intention to do vasectomy.

Acknowledgments: We would like to thank for married men who have participated in the research.

Conflict of Interest: We do not have any conflict of interest.

\section{Source of Funding: None}

Ethical Clearance: The study was approved by the Institute of Health Sciences Surya Mitra Husada.

\section{References}

1. Rizkitama AA, Indrawati F. Hubungan Pengetahuan, Persepsi, Sosial Budaya Dengan Peran Aktif Pria Dalam Vasektomi Di Kecamatan Paguyangan Kabupaten Brebes Tahun 2011-2012. Unnes J Public Heal. 2015;4(1):48-54.

2. Nesro J, Sendo EG, Yesuf NT, Sintayehu Y. Intention to use vasectomy and associated factors among married men in Addis Ababa, Ethiopia. BMC Public Health [Internet]. 2020 Aug 12 [cited 2020 Nov 29];20(1):1228. Available from: https://bmcpublichealth.biomedcentral.com/ articles/10.1186/s12889-020-09316-X

3. Ayele AD, Beyene FY, Wudineh KG, Kassa BG,
Goshu YA, Mihretie GN. Intention to use vasectomy and its associated factors among married men in Debre Tabor Town, North West Ethiopia, 2019. Tu W-J, editor. PLoS One [Internet]. 2020 Sep 3 [cited 2020 Nov 29];15(9):e0238293. Available from: https://dx.plos.org/10.1371/journal.pone.0238293

4. Ahmed S, Li Q, Liu L, Tsui AO. Maternal deaths averted by contraceptive use: An analysis of 172 countries. Lancet [Internet]. 2012 [cited $2020 \mathrm{Nov}$ 29];380(9837):111-25. Available from: https:// pubmed.ncbi.nlm.nih.gov/22784531/

5. Alemayehu M, Belachew T, Tilahun T. Factors associated with utilization of long acting and permanent contraceptive method among married women of reproductive age in Mekelle town, Tigray region, north Ethiopia. BMC Pregnancy Childbirth [Internet]. 2012 Jan 26 [cited 2020 Nov 29];12(1):6. Available from: http:// bmcpregnancychildbirth.biomedcentral.com/ articles/10.1186/1471-2393-12-6

6. World Health Organization. Contraception: fact sheet: family planning enables people to make informed choices about their sexual and reproductive health [Internet]. World Health Organization; 2014. Available from: https://apps. who.int/iris/handle/10665/112319

7. Sutinah S. Partisipasi laki-laki dalam program Keluarga Berencana di era masyarakat postmodern. Masyarakat, Kebud dan Polit [Internet]. 2017 Sep 20 [cited 2020 Aug 5];30(3):290. Available from: https://e-journal.unair.ac.id/MKP/article/ view/4116

8. Dinas Kesehatan dan Keluarga Berencana. Profil Kesehatan Kota Madiun Tahun 2018. Madiun: Dinas Kesehatan dan Keluarga Berencana; 2019.

9. Akafuah RA, Sossou MA. Attitudes toward and use of knowledge about family planning among Ghanaian men. Int J Mens Health [Internet]. 2008 Jun [cited 2020 Nov 30];7(2):109-20. Available from:/record/2008-13126-001

10. Anderson JE, Jamieson DJ, Warner L, Kissin DM, Nangia AK, MacAluso M. Contraceptive sterilization among married adults: National data on who chooses vasectomy and tubal sterilization. Contraception [Internet]. 2012 Jun [cited 2020 Apr 7];85(6):552-7. Available from: http://www.ncbi. nlm.nih.gov/pubmed/22133657

11. Sharma V, Le B V., Sheth KR, Zargaroff S, Dupree 
JM, Cashy J, et al. Vasectomy demographics and postvasectomy desire for future children: Results from a contemporary national survey. Fertil Steril [Internet]. 2013 Jun 1 [cited 2020 Nov 30];99(7):1880-5. Available from: https:// www.scholars.northwestern.edu/en/publications/ vasectomy-demographics-and-postvasectomydesire-for-future-childr

12. Tuloro T, Deressa W, Ali A, Davey G. The role of men in contraceptive use and fertility preference in Hossana town, Southern Ethiopia. Ethiop J Heal Dev [Internet]. 2009 Oct 16 [cited 2020 Nov 30];20(3). Available from: https://www.ajol.info/ index.php/ejhd/article/view/46826

13. Cook LA, Van Vliet HA, Lopez LM, Pun A, Gallo MF. Vasectomy occlusion techniques for male sterilization [Internet]. Vol. 2014, Cochrane Database of Systematic Reviews. John Wiley and Sons Ltd; 2014 [cited 2020 Nov 30]. Available from: http://doi.wiley.com/10.1002/14651858. CD003991.pub4

14. Mohamad Al-Ali B, Shamloul R, Ramsauer J, Bella AJ, Scrinzi U, Treu T, et al. The Effect of Vasectomy on the Sexual Life of Couples. J Sex Med [Internet]. 2014 Sep 1 [cited 2020 Nov 30];11(9):2239-42. Available from: https://linkinghub.elsevier.com/ retrieve/pii/S1743609515308511

15. Shongwe $\mathrm{P}$, Ntuli B, Madiba S. Assessing the acceptability of vasectomy as a family planning option: A qualitative study with men in the Kingdom of Eswatini. Int $\mathrm{J}$ Environ Res Public Health [Internet]. 2019 Dec 2 [cited 2020 Apr 13];16(24). Available from: http://www.ncbi.nlm. nih.gov/pubmed/31861151

16. Ababa A. Knowledge, Attitudes and Practices (KAP) Survey, Permanent Method of Family Planning in four regions of Ethiopia. Ethiopia: USAID; 2017.

17. Sood G. Vasectomy: a study of attitudes, beliefs, knowledge and practices among literate men in Punjab, India. Int $\mathrm{J}$ Reprod Contracept Obs Gynecol [Internet]. 2014 Jan 2 [cited 2020 Nov 30];3(2):418-23. Available from: http://dx.doi. org/10.5455/2320-1770.ijrcog20140627

18. OdetteM.Vasectomy Acceptability within Rwandan Family Planning Policy [Internet]. University of Rwanda; 2014 [cited 2020 Nov 30]. Available from: http://dr.ur.ac.rw/handle/123456789/186
19. Musrizal YH. Vasectomy Intention among Married Males in Indonesia | Journal of Health Research. J Heal Res [Internet]. 2015 [cited 2020 Nov 30];29(3). Available from: https://he01.tci-thaijo. org/index.php/jhealthres/article/view/97173

20. Mahat K, Pacheun O. Intention to Accept Vasectomy among Married Men in Kathmandu, Nepal. Asia J Public Heal [Internet]. 2010 [cited 2020 Nov 30];1(1). Available from: http:// ns2.ph.mahidol.ac.th/phklb/knowledgefiles/4 Intention_to_Accept_Vasectomy.pdf

21. Awie BE. Men's knowledge and attitude towards vasectomy in east Wollega zone of Oromia region, Ethiopia [Internet]. undefined. [South Africa]: University of South Africa; 2014 [cited 2020 Nov 30]. Available from: http://uir.unisa.ac.za/ bitstream/handle/10500/18696/dissertation_awie_ be.pdf?isAllowed $=\mathrm{y} \&$ sequence $=1$

22. Murti B. Desain dan Ukuran Sampel untuk Penelitian Kuantitatif dan Kualitatif di Bidang Kesehatan. Yogyakarta: Gadjah Mada University Press; 2013.

23. Satria G. Perilaku Pemilihan Metoda Kontrasepsi Vasektomi Pada Pria Pasangan Usia Subur Berdasarkan Theory of Planned Behavior (TPB) Di Kecamatan Kenjeran Surabaya. Universitas Airlangga; 2015.

24. Friedman M. Buku Ajar Keperawatan Keluarga: Riset, Teori, dan Praktik. Jakarta: EGC; 2010.

25. Wahyuni NPDS, Suryani N, Murdani K P. Hubungan Pengetahuan dan Sikap Akseptor $\mathrm{Kb}$ Pria Tentang Vasektomi Serta Dukungan Keluarga dengan Partisipasi Pria dalam Vasektomi (di Kecamatan Tejakula Kabupaten Buleleng). J Magister Kedokt Kel [Internet]. 2013 [cited 2020 Nov 11];1(1):13501. Available from: http://jurnal. pasca.uns.ac.id

26. Puspita SD. Dukungan Istri, Peran Petugas KB dalam Peningkatan Partisipasi Pria dalam Keluarga Berencana. Arter J Ilmu Kesehat [Internet]. 2019 Nov 13 [cited 2020 Sep 10];1(1):43-9. Available from: http://arteri.sinergis.org/index.php/arteri/ article/view/19

27. Tangkilisan HNS. Manajemen publik. Jakarta: Gramedia Widiasarana Indonesia; 2005.

28. Ariyanti L, Dasuki D, Wilopo SA. Sumber daya kesehatan dan unmet need: analisis tingkat provinsi. Ber Kedokt Masy [Internet]. 2017 Jan 1 [cited 2020 
Nov 10];33(1):49. Available from: https://jurnal. ugm.ac.id/bkm/article/view/9868

29. Handayani L, Suharmiati S, Hariastuti I, Latifah C. Peningkatan Informasi Tentang KB: Hak Kesehatan Reproduksi Yang Perlu Diperhatikan
Oleh Program Pelayanan Keluarga Berencana. Bul Penelit Sist Kesehat [Internet]. 2013 [cited 2020 Nov 9];15(3 Jul). Available from: http://ejournal. litbang.kemkes.go.id/index.php/hsr/article/ view/3003 